\title{
Article
}

\section{Foreign Aid and Inclusive Development: Updated Evidence from Africa, 2005- 2012*}

Asongu, Simplice A. and Nwachukwu, Jacinta Chikaodi

Available at http://clok.uclan.ac.uk/24926/

Asongu, Simplice A. and Nwachukwu, Jacinta Chikaodi ORCID: 0000-00032987-9242 (2017) Foreign Aid and Inclusive Development: Updated Evidence from Africa, 2005-2012*. Social Science Quarterly, 98 (1). pp. 282-298. ISSN 0038-4941

It is advisable to refer to the publisher's version if you intend to cite from the work. http://dx.doi.org/10.1111/ssqu.12275

For more information about UCLan's research in this area go to http://www.uclan.ac.uk/researchgroups/ and search for <name of research Group>.

For information about Research generally at UCLan please go to http://www.uclan.ac.uk/research/

All outputs in CLoK are protected by Intellectual Property Rights law, including Copyright law. Copyright, IPR and Moral Rights for the works on this site are retained by the individual authors and/or other copyright owners. Terms and conditions for use of this material are defined in the policies page.

\section{CLoK}

Central Lancashire online Knowledge www.clok.uclan.ac.uk

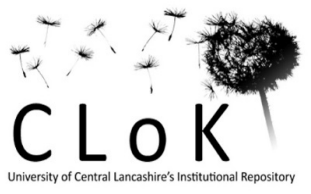




\section{Foreign Aid and Inclusive Development: Updated Evidence from Africa, 2005-2012*}

Asongu, S. A., Nwachukwu, J. C.

Author post-print (accepted) deposited by Coventry University's Repository

Original citation \& hyperlink:

Asongu, SA \& Nwachukwu, JC 2016, 'Foreign Aid and Inclusive Development:

Updated Evidence from Africa, 2005-2012*' Social Science Quarterly, vol (In Press).

DOI: $10.1111 /$ ssqu. 12275

https://dx.doi.org/10.1111/ssqu. 12275

DOI $10.1111 /$ ssqu. 12275

ISSN 0038-4941

ESSN $\quad 1540-6237$

Publisher: Wiley

This is the peer reviewed version of the following article: Asongu, SA \& Nwachukwu, JC 2016, 'Foreign Aid and Inclusive Development: Updated Evidence from Africa, 2005-2012*' Social Science Quarterly, vol (98). DOI:

10.1111/ssqu.12275, which has been published in final form at https://dx.doi.org/10.1111/ssqu.12275 This article may be used for noncommercial purposes in accordance with Wiley Terms and Conditions for SelfArchiving.

Copyright $(\subseteq$ and Moral Rights are retained by the author(s) and/ or other copyright owners. A copy can be downloaded for personal non-commercial research or study, without prior permission or charge. This item cannot be reproduced or quoted extensively from without first obtaining permission in writing from the copyright holder(s). The content must not be changed in any way or sold commercially in any format or medium without the formal permission of the copyright holders.

This document is the author's post-print version, incorporating any revisions agreed during the peer-review process. Some differences between the published version and this version may remain and you are advised to consult the published version if you wish to cite from it. 


\title{
Foreign Aid and Inclusive Development: Updated Evidence from Africa, 2005-2012
}

\author{
Simplice A. Asongu* \\ African Governance and Development Institute, \\ P.O. Box 8413 Yaoundé, Cameroon. \\ E-mail: asongusimplice@yahoo.com /asongus@ afridev.org
}

\author{
Jacinta C. Nwachukwu \\ School of Economics, Finance and Accounting, \\ Faculty of Business and Law, \\ Coventry University \\ Priory Street, Coventry, CV1 5DH, UK \\ Email: jacinta.nwachukwu@ coventry.ac.uk
}

Direct all correspondence to Simplice A. Asongu.

Simplice A. Asongu shall share all data and coding for replication purposes.

The authors are indebted to the editor and referees for constructive comments. 


\begin{abstract}
Objectives- Motivated by the April 2015 World Bank Publication on MDGs which reveals that poverty has been declining in all regions of the world with the exception of African countries, this study investigates the effects of a plethora of foreign aid dynamics on inequality adjusted human development.

Methods- Contemporary and non-contemporary OLS, Fixed-effects and a system GMM technique with forward orthogonal deviations are employed. The empirical evidence is based on an updated sample of 53 African countries for the period 2005-2012.

Results - The following findings are established. First, the impacts of aid dynamics with high degrees of substitution are positive. These include aid for: social infrastructure, economic infrastructure, the productive sector and multi-sectors. Second, the effect of humanitarian assistance is consistently negative across specifications and models. Third, the effects of programme assistance and action on debt are ambiguous because they become positive with the GMM technique.

Conclusions - Justifications for these changes and clarifications with respect to existing literature are provided. Policy implications are discussed in the light of the post-2015 development agenda. We also provide some recommendations for a rethinking of theories and models on which development assistance is based.
\end{abstract}

JEL Classification: B20; F35; F50; O10; O55

Keywords: Foreign Aid; Political Economy; Development; Africa 


\section{Introduction}

Our interest in focusing on Africa is twofold. First, consistent with Asongu (2015a), while South East Asian and Latin American countries have been experiencing decreasing levels of inequality, that of Africa has been increasing. Second, in light of a recent World Bank report on attainment of the Millennium Development Goals (MDGs), while extreme poverty has decreased in all regions of the World, it has been increasing in Africa. According to the report, about 45 percent of nations in Sub-Saharan Africa (SSA) are still off-track from achieving the Millennium Development extreme poverty target (Caulderwood, 2015; Asongu \& Kodila-Tedika, 2015).

\section{Figure 1: Comparative regional poverty levels}

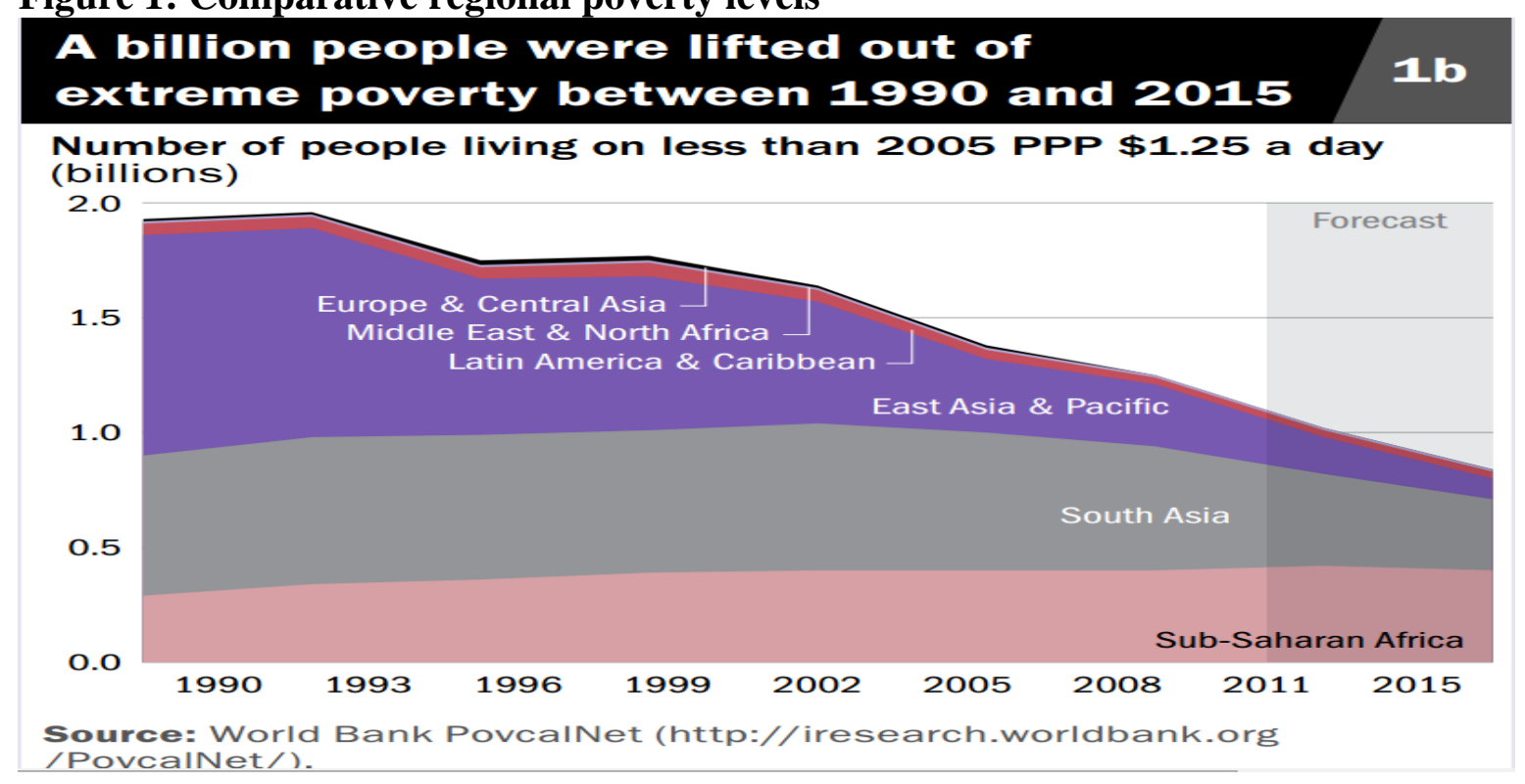

The above picture contrasts with narratives of recent-growth resurgence in Africa from the mid 1990s (Fosu, 2015a, p.44; Alan \& Carlyn, 2015, p. 598), inter alia: poverty in the sub-region decreasing in tandem with other regions of the world (Fosu, 2015a), or Africa being on time for the MDG poverty target (Pinkivskiy \& Sala-i-Martin, 2014) ${ }^{1}$. This stream of the literature has been motivated by a strand on 'Africa rising' (Leautier, 2012) and/or an 'African growth miracle' (Young, 2012) which may be more inclined towards extolling the rewards of capital accumulation and a neoliberal ideology ${ }^{2}$ by fundamentally neglecting

\footnotetext{
${ }^{1}$ According to Pinkivskiy and Sala-i-Martin (2014), with the exception of the Democratic Republic of Congo, African countries attained the MDGs poverty target by 2014 or one year in advance.

${ }^{2}$ The neoliberal agenda here refers to policies supporting extensive economic liberalization such as free trade, deregulation, fiscal austerity and cut-down in government spending.
} 
issues like ecology, job sustainability and inequality (Obeng-Odoom, 2014). It follows that Africa is still far from attaining the MDGs because its growth has been marred by rising inequality (Blas, 2014). The concern regarding exclusive growth in Africa has also been the motivation behind an interesting documentation of studies by Fosu (2015bc) which are devoted to elucidating: (i) myths surrounding Africa's recent growth and (ii) the role of institutions in this underlying resurgence.

The post-2015 challenges of sustainable development have clearly articulated the need for more inclusive policies (United Nations: UN, 2013, pp. 7-13). According to the narrative, development assistance is a critical factor to addressing this issue. In this respect, pitfalls of the past can be avoided, inter alia: 'Output may be growing, and yet the mass of the people may be becoming poorer' (Lewis, 1955). 'Lewis led all developing countries to water, proverbially speaking, some African countries have so far chosen not to drink' (Amavilah, 2014). The celebrated 'capital in the $21^{\text {st }}$ century' from Piketty (2014) has taken African nations to water again and this study partially assesses the challenging policy syndrome of how development assistance can help them to drink in the contemporary era (Asongu, $2015 \mathrm{a})^{3}$.

The above intuition is inconsistent with a recent strand in the literature which has raised doubts about the effectiveness of foreign aid (Ghosh, 2013; Krause, 2013; Monni \& Spaventa, 2013; Banuri, 2013; Titumir \& Kamal, 2013; Wamboye et al., 2013; Marglin, 2013). According to this narrative, aid to developing countries is substantially motivated by a neo-colonial agenda (Amin, 2014). A stance that is shared by (i) Kindiki (2011) who has recommended Africa to strategically limit its reliance on international aid systems and (ii) Ndlovu-Gatsheni (2013) on the continent's entrapment in neo-colonial webs of influence. Amin (2014) has further emphasised that models of development in developing countries should reflect what is needed by poor nations, as opposed to what donors think is good for them. The need for developed countries to guide developing nations towards industrialisation in the view of Piketty is indirectly shared by Obeng-Odoom (2013) who has also recommended that policies towards development assistance should be guided by genuine needs in recipient countries. This strand is broadly consistent with aid literature on the need to

\footnotetext{
${ }^{3}$ Consistent with Asongu (2015a), foreign aid can be instrumental in preparing developing countries for industrialisation in the narrative of Piketty (2014) and not in view of Kuznets' $(1955,1971)$; conjectures which sustain an inverted U-shape nexus between inequality and industrialisation. Accordingly, by focusing more on inclusive human development as opposed to growth, concerns of "immiserizing growth" (Bhagwati, 1958) can be tackled. Immiserizing occurs when economic growth is associated with disequalizing income distribution externalities.
} 
rethink foreign aid policies, notably the Eubank (2012) Somaliland hypothesis, Moyo's (2009) Dead Aid and Collier's (2007) Bottom Billion ${ }^{4}$.

In the light of the above, a recent stream of African development work has presented cases for the appealing effect of foreign aid on African institutions (Asongu \& Jellal, 2013; Kangoye, 2013; Efobi et al., 2014). Some conclusions in this stream include, among others that: (i) the positive effect of aid depends on a conducive policy environment, measurement of aid and specification of the aid-growth nexus (Gyimah-Brempong \& Racine, 2014), (ii) aid in primary education positively affects growth (Asiedu, 2014) and (iii) in Sierra Leone, only aid reflected in grants have effects that are pro-poor, with the impact more apparent in the longrun (Kargbo \& Sen, 2014).

The above strand is also a consequence of a number of qualitative and quantitative studies that have focused on reinventing foreign aid (Easterly, 2008). These include, among others: the experiment on ending poverty by Sachs; the World Bank and International Monetary Fund (IMF) Poverty Reduction Strategy (PRS); the cost effectiveness of interventions (Banerjee \& He, 2008); the imperative for more rigorous evaluation (Pritchett, 2008); Randomised Control Trials (RCTs, Duflo \& Kremer, 2008); amputation, intensification and policy change based reforms (Pritchett \& Woolcook, 2008); more articulation on 'searching for solutions' than on 'planning for solutions' (Easterly, 2006); APC or Advanced Purchase Commitment (Kremer, 2008); novel initiatives at the global level (Radelet \& Levine, 2008); 'aid vouchers' to provide incentives for better/competitive service delivery by agencies of aid (Easterly, 2002, 2008) and a broad range of measures for more inclusive policies on foreign land acquisition (Osabuohien, 2015).

With knowledge that in the transition from Millennium Development Goals (MDGs) to Sustainable Development Goals (SDGs), the policy debate has substantially shifted to inclusive development, the present study responds to the policy challenge of promoting inclusive development in Africa by assessing the role of foreign aid on inclusive human development. In so doing, the 'questionable economics of development assistance in Africa' (Asongu, 2014a) has also been clarified with updated data. The underlying study leaves room for improvement in at least three areas. First, it overlooks the heterogeneity of aid dynamics. Accordingly, three types of aid variables have been employed: total aid, aid from the Development Assistance Committee (DAC) and aid from Multilateral Donors (MD). We

\footnotetext{
${ }^{4}$ There is also a heated debate on the effect of foreign aid on institutions in Africa. The interested reader can start from Okada \& Samreth (2012) before exploring the plethora of studies that are focused on the underlying paper, inter alia: Asongu (2012, 2013), Asongu \& Jellal (2013) and Efobi et al. (2014).
} 
complement this dimension on variables by using seven different types of aid indicators, namely: aid to social infrastructure, aid to economic infrastructure, aid to the productive sector, aid to the multi-sector, programme assistance, action on debt and humanitarian assistance. The intuition for this complementarity is that the effect of aid on inclusive human development should depend on the type of aid because there are various motives behind it. These same variables have been recently used by Efobi et al. (2014) in clarifying murky empirical conclusions on the effect of foreign aid on corruption.

Second, we employ a more robust methodology. The Two-Stage Least Squares method employed by the underlying study (Asongu, 2014a) fails to control for cross-sectional dependence and country-specific effects. We employ Ordinary Least Squares (OLS), FixedEffects (FE) and the System Generalised Method of Moments (GMM) regressions. The GMM estimation is modelled with forward orthogonal deviations as opposed to differencing so as to control for cross-sectional dependence. Third, the effect of foreign aid on development may be non-contemporaneous. We address this concern by modelling aid as both contemporary and non-contemporary.

The rest of the study is organised as follows. Section 2 briefly engages theoretical underpinnings. Section 3 discusses the data and methodology. The empirical analysis and results are covered in Section 4. We conclude with Section 5.

\section{Theoretical underpinnings and reinventing foreign aid for inclusive development}

The theoretical underpinnings linking foreign aid channels to inclusive development in developing countries build on two main theoretical views that have been documented to elicit Africa's poverty tragedy on the one hand and the ineffectiveness of foreign aid on the other. First, Kuada (2015) has argued that a substantial paradigm shift is needed to understand recent poverty trends in Africa. The author has suggested that a 'soft economics' approach focusing on human capability development should be given more emphasis in relation to the 'strong economics' paradigm based on structural adjustment policies. This suggestion for a paradigm shift is consistent with a recent theory by Asongu and Jellal (2016) on foreign aid policy which postulates that domestic and private investments (for economic growth and inclusive development) can be better achieved if foreign aid is channelled through mechanisms that reduce the burden of the taxation system on the private sector of recipient nations. The narrative of Kuada (2015) for understanding trends in high unemployment, 
poverty and exclusive growth in Africa is broadly consistent with a recent stream of African development literature which has responded to the MDG-related poverty trends by suggesting mechanisms by which foreign aid could be tailored to achieve more employment, inclusive growth and poverty alleviation (Jones \& Tarp, 2015; Simpasa et al., 2015; Jones et al., 2015; Asongu \& Tchamyou, 2015; Page \& Shimeles, 2015; Page \& Söderbom, 2015).

We briefly discuss why reinventing foreign aid for inclusive development is consistent with the celebrated literature of Thomas Piketty and Simon Kuznets. Asongu (2015a) has surveyed over 200 studies to make a case for the need to overhaul development assistance for more inclusive economic growth and development. The main focus of the survey is centred on the argument that development assistance should not be used to guide poor countries towards industrialisation in the perspective of Kuznets, but in the manner outlined by Piketty. According to the authors, abandoning Kuznets' view that inclusive development is achieved with progress in industrialisation on the one hand and placing inclusive development at the heart of foreign aid policies could lead to outcomes that are consistent with the post-2015 sustainable development agenda.

\section{Data and Methodology}

\subsection{Data}

We examine a panel of 53 African countries with data from the Organisation of Economic Co-operation and Development (OECD), the United Nations Development Program (UNDP) and the World Bank for the period 2005 to 2012. The periodicity and aid indicators are consistent with those employed by Efobi et al. (2014) in clarifying the debate on 'the effect of foreign aid on corruption'. The underlying debate is from: Okada and Samreth (2012), Asongu (2013), Asongu and Jellal (2013). The dependent variable which is the inequality adjusted human development index (IHDI) is in accordance with that employed by Asongu (2014a) we also seek to clarify. The persistence of the dependent variable is also consistent with the choice of an estimation technique that involves the introduction of a lagged dependent in the specification. To this end, after the choice of the Generalised Method of Moments (GMM), a pilot assessment with preliminary findings shows that stretching the periodicity further compromises the validity of estimations; notably it results in instrument proliferation.

Table 1: Definition of variables, sources and summary statistics

\begin{tabular}{ccccccc}
\hline Definitions/Sources & Mean & S.D & Min & Max & Obs \\
\hline
\end{tabular}




\begin{tabular}{|c|c|c|c|c|c|c|}
\hline $\begin{array}{l}\text { Inclusive } \\
\text { development }\end{array}$ & $\begin{array}{l}\text { Inequality Adjusted Human Development Index } \\
(\log ) / \text { UNDP, World Bank WDI. }\end{array}$ & 0.486 & 0.130 & 0.129 & 0.809 & 351 \\
\hline $\begin{array}{l}\text { Aid to Social } \\
\text { Infrastructure }\end{array}$ & $\begin{array}{l}\text { Foreign aid directed for human development } \\
\text { purposes such as education, water supply and } \\
\text { sanitation (log)/OECD. }\end{array}$ & 2.012 & 0.622 & 0.113 & 3.077 & 424 \\
\hline $\begin{array}{l}\text { Aid to } \\
\text { Economic } \\
\text { Infrastructure }\end{array}$ & $\begin{array}{l}\text { Foreign aid directed at infrastructure like } \\
\text { transport, communication and energy }(\log ) / O E C D .\end{array}$ & 0.812 & 1.201 & -2.000 & 3.067 & 415 \\
\hline $\begin{array}{l}\text { Aid to } \\
\text { Productive } \\
\text { Sector }\end{array}$ & $\begin{array}{l}\text { Foreign aid directed at the productive sector like } \\
\text { agriculture, industry, mining, construction, trade } \\
\text { and tourism }(\log ) / O E C D \text {. }\end{array}$ & 1.017 & 0.830 & -1.699 & 2.741 & 424 \\
\hline $\begin{array}{l}\text { Aid to Multi } \\
\text { Sector }\end{array}$ & $\begin{array}{l}\text { Foreign aid directed at other sectorial development } \\
\text { like rural development }(\log ) / \mathrm{OECD} \text {. }\end{array}$ & 1.023 & 0.682 & -1.699 & 2.541 & 424 \\
\hline $\begin{array}{l}\text { Programme } \\
\text { Assistance }\end{array}$ & $\begin{array}{l}\text { Foreign aid directed towards program related } \\
\text { assistance like food aid, disaster and war } \\
(\log ) / O E C D \text {. }\end{array}$ & 1.116 & 0.924 & -2.000 & 3.103 & 350 \\
\hline Action on debt & Aid directed towards debt relief (log)/OECD. & 0.535 & 1.310 & -2.000 & 4.045 & 321 \\
\hline $\begin{array}{l}\text { Humanitarian } \\
\text { Assistance }\end{array}$ & $\begin{array}{l}\text { Aid allocated for Humanitarian Assistance } \\
(\log ) / O E C D\end{array}$ & 0.894 & 1.004 & -2.000 & 3.038 & 400 \\
\hline
\end{tabular}

S.D: Standard Deviation. Min: Minimum. Max: Maximum. Obs: Observations. Log: logarithm. OECD: Organisation for Economic Cooperation and Development. UNDP: United Nations Development Program. WDI: World Bank Development Indicators. The development assistance data are disbursements of multilateral aid from DAC countries.

The aid and dependent variables are summarised in Table 1. The summary statistics show that the variables are quite comparable. From the variations, we can expect reasonable estimated relationships to emerge. The aid variables are defined in logarithms to enable comparisons in means and standard deviations. The development assistance data are disbursements of multilateral aid from DAC countries. The employment of control variables proliferates instruments or limits 'over-identification restrictions' which substantially bias the system GMM results. Accordingly, for the purpose of limiting instrument proliferation, some GMM specifications have limited or no control variables (see Osabuohien \& Efobi, 2013, p. 303).

The correlation matrix in Table 2 enables us to mitigate multicollinearity and overparameterization issues apparent in the first-four variables; notably in aid for: social infrastructure, economic infrastructure, the production sector and the multi-sector.

Table 2: Correlation matrix

\begin{tabular}{rrrrrrrr}
\hline SocioInfra & EcoInfra & ProdSec & MultiSec & Prog. Assis & Debt Action & Humani & IHDI \\
\hline 1.000 & 0.756 & 0.760 & 0.784 & 0.284 & 0.111 & 0.419 & -0.184 \\
SocioInfra
\end{tabular}




\begin{tabular}{llllllll}
\hline 1.000 & 0.675 & 0.693 & 0.203 & 0.155 & 0.150 & 0.029 & EcoInfra \\
& 1.000 & 0.733 & 0.304 & 0.112 & 0.262 & -0.139 ProdSec \\
& & 1.000 & 0.297 & 0.067 & 0.349 & -0.189 MultiSec \\
& & & 1.000 & -0.022 & 0.351 & -0.359 Prog. Assis \\
& & & & 1.000 & 0.006 & -0.007 Debt Action \\
& & & & & 1.000 & -0.553 Humani \\
& & & & & & & \\
& & & & & &
\end{tabular}

SocioInfra: Aid to Social Infrastructure \& Services. EcoInfra: Aid to Economic Infrastructure and Services. ProdSec: Aid to Production Services. MultiSec: Aid to Multi Sector Development. Prog. Assis: Programme Assistance. Debt Action: Aid for debt relief. Humani: Aid for Humanitarian Assistance. IHDI: Inequality adjusted Human Development Index.

\subsection{Methodology}

Consistent with the motivation, we employ three estimation techniques: panel OLS, panel Fixed-effects (FE) and Dynamic System GMM. While the first-two independently entail both contemporary and non-contemporary specifications, the third is simultaneously contemporary and non-contemporary. OLS and FE are Heteroscedasticity and Autocorrelation Consistent (HAC) in standard errors. The choice of a FE or random-effect (RE) specification is contingent on the outcome of the Hausman test for endogeneity.

The GMM estimation consists of employing the Arellano and Bover (1995) technique. Instead of using differencing in the instrumentation process, we prefer forward orthogonal deviations. Such a specification is more efficient in the presence of cross-sectional dependence to avoid bias in estimated coefficients (Baltagi, 2008). As shown by Love and Zicchino (2006), the employment of forward orthogonal deviations controls for specificeffects arising from cross-sectional dependence. In this light, one period lags in the regressors are appropriate since they are not correlated with the transformed error term. Moreover, the adoption of one lag is also in accordance with the baseline OLS and FE non-contemporary specifications.

The modelling is in line with Roodman (2009ab) and specifications are two-step or heteroscedasticity-consistent, because one-step specifications assume the presence of homoscedasticity. The validity of models is further verified by ensuring that the results satisfy diagnostics of post-estimation. In accordance with Asongu and De Moor (2015), the study uses four information criteria to assess the validity of estimated models. First, in order to investigate the absence of autocorrelation in the residuals, the null hypothesis corresponding to the second-order Arellano and Bond (1991) autocorrelation test in difference (AR(2)) should not be rejected. Second, for the instruments to be valid, the null hypothesis corresponding to the Hansen and Sargan over-identification restrictions (OIR) test should also not be rejected. In essence, the Sargan (Hansen) OIR test which is based on homoscedasticity 
(heteroscedasticity) is not robust but not weakened by instruments. Moreover, the modelling exercise is tailored to restrict over-identification or limit instrument proliferation by ensuing that for each specification, the number of cross-sections is higher than the corresponding number of instruments. Third, the Difference in the Hansen Test (DHT) for exogeneity of instruments is employed to further examine the validity of the Hansen OIR test. Fourth, the Fisher test used to examine the joint validity of estimated parameters should be significant. For brevity, we do not present the equations which can be provided upon request.

\section{Empirical Results}

Table 3 presents contemporary and non-contemporary results. Panel A shows OLS while Panel B reveals FE estimations. The specifications are tailored to control for the multicollinearity issues identified in Table 2. Only FE estimations are relevant to Panel B because the null hypotheses of the Hausman test for endogeneity are rejected, confirming the presence of endogeneity.

The following findings are established in Panel A. First, aid for program and humanitarian assistance affects the IHDI negatively. Second, there is no apparent impact from action on debts. Third, the effects of the aid dynamics with a high degree of substitution are consistently positive across specifications. Fourth, from a broad perspective, magnitudes of effects from non-contemporary specifications are slightly higher.

These results are noticeable with the FE estimations in Panel B. First, the previously insignificant effects from action on debt are now negatively significant. Second, the previously negative effects of program and humanitarian assistance are no longer apparent. Third, but for aid to multi-sector development, the other three highly correlated aid dynamics have significant positive effects as in Panel A.

Table 3: Contemporary and non-contemporary OLS and fixed-effects

Dependent variable: Inequality adjusted Human Development Index (IHDI) 
Panel A: Baseline Contemporary and Non-contemporary effects (HAC SE OLS)

\section{Contemporary effects}

\begin{tabular}{|c|c|c|c|c|c|}
\hline Constant & $\begin{array}{l}0.410 * * * \\
(0.000)\end{array}$ & $\begin{array}{l}0.499 * * * \\
(0.000)\end{array}$ & $\begin{array}{l}0.495 * * * \\
(0.000)\end{array}$ & $\begin{array}{l}0.472 * * * \\
(0.000)\end{array}$ & Constant \\
\hline Prog. Assistance & $\begin{array}{l}-\mathbf{0 . 0 3 4} * * * * \\
(\mathbf{0 . 0 0 3 )}\end{array}$ & $\begin{array}{l}-\mathbf{0 . 0 3 7} * * * \\
(0.000)\end{array}$ & $\begin{array}{l}-\mathbf{0 . 0 3 3} * * * * \\
(\mathbf{0 . 0 0 4 )}\end{array}$ & $\begin{array}{l}-0.030 * * * \\
(0.004)\end{array}$ & Prog. Assistance (-1) \\
\hline Action on Debt & $\begin{array}{l}-0.0004 \\
(0.954)\end{array}$ & $\begin{array}{l}-0.002 \\
(0.679)\end{array}$ & $\begin{array}{l}0.0002 \\
(0.971)\end{array}$ & $\begin{array}{l}0.0003 \\
(0.956)\end{array}$ & Action on Debt $(-1)$ \\
\hline Hum. Assistance & $\begin{array}{l}-0.052 * * * \\
(0.000)\end{array}$ & $\begin{array}{l}-0.041 * * * \\
(0.003)\end{array}$ & $\begin{array}{l}-0.043 * * * \\
(0.005)\end{array}$ & $\begin{array}{l}-0.047 * * * \\
(0.001)\end{array}$ & Hum. Assistance (-1) \\
\hline Social Infrastructure & $\begin{array}{l}0.062 * * * \\
(0.003)\end{array}$ & -- & -- & --- & Social Infrastructure(-1) \\
\hline Econ. Infrastructure & --- & $\begin{array}{l}\mathbf{0 . 0 3 7} * * * \\
(\mathbf{0 . 0 0 0 )}\end{array}$ & --- & --- & Econ. Infrastructure (-1) \\
\hline Productive Sector & --- & --- & $\begin{array}{l}0.031 * * \\
(0.036)\end{array}$ & --- & Productive Sector(-1) \\
\hline Multi Sector & --- & --- & --- & $\begin{array}{l}\mathbf{0 . 0 5 0} * * * \\
(\mathbf{0 . 0 0 3 )}\end{array}$ & Multi Sector(-1) \\
\hline Adjusted $\mathrm{R}^{2}$ & 0.308 & 0.376 & 0.271 & 0.290 & Adjusted R ${ }^{2}$ \\
\hline Fisher & $27.22 * * *$ & $36.47 * * *$ & $22.926 * * *$ & $25.017 * * *$ & Fisher \\
\hline Countries & 42 & 42 & 42 & 42 & Countries \\
\hline Observations & 236 & 236 & 236 & 236 & Observations \\
\hline
\end{tabular}

Non-Contemporary effects

\begin{tabular}{|c|c|c|c|}
\hline $\begin{array}{l}0.399 * * * \\
(0.000)\end{array}$ & $\begin{array}{l}0.498 * * * \\
(0.000)\end{array}$ & $\begin{array}{l}0.498 * * * \\
(0.000)\end{array}$ & $\begin{array}{l}0.471 * * * \\
(0.000)\end{array}$ \\
\hline$-0.033 * * *$ & $-0.037 * * *$ & $-0.031 * * *$ & $-\mathbf{0 . 0 3 0} * * *$ \\
\hline$(0.000)$ & $(0.000)$ & (0.007) & $(0.006)$ \\
\hline-0.001 & -0.004 & -0.0009 & -0.0004 \\
\hline$(0.842)$ & $(0.537)$ & $(0.899)$ & $(0.955)$ \\
\hline $\begin{array}{l}-0.054 * * * \\
(0.000)\end{array}$ & $\begin{array}{l}-0.042 * * * \\
(0.003)\end{array}$ & $\begin{array}{l}-0.044 * * * \\
(0.007)\end{array}$ & $\begin{array}{l}-0.048 * * * \\
(0.001)\end{array}$ \\
\hline $\begin{array}{l}\mathbf{0 . 0 6 9} * * * \\
(0.000)\end{array}$ & --- & --- & --- \\
\hline --- & $\begin{array}{l}0.043 * * * \\
(\mathbf{0 . 0 0 0 )}\end{array}$ & --- & --- \\
\hline --- & --- & $\begin{array}{l}\text { 0.031*** } \\
(0.039)\end{array}$ & --- \\
\hline --- & --- & --- & $\begin{array}{l}0.054 * * * \\
(0.004)\end{array}$ \\
\hline 0.316 & 0.407 & 0.261 & 0.286 \\
\hline 25.31*** & $37.06 * * *$ & $19.57 * * *$ & $22.08 * * *$ \\
\hline 41 & 41 & 41 & 41 \\
\hline 211 & 211 & 211 & 211 \\
\hline
\end{tabular}

Panel B: Contemporary and Non-contemporary effects (HAC SE Panel Fixed-Effects)

\section{Contemporary effects}

\begin{tabular}{|c|c|c|c|c|c|}
\hline Constant & $\begin{array}{l}\mathbf{0 . 3 9 3} * * * \\
(0.000)\end{array}$ & $\begin{array}{l}\mathbf{0 . 4 3 3} * * * \\
(0.000)\end{array}$ & $\begin{array}{l}0.427 * * * \\
(0.000)\end{array}$ & $\begin{array}{l}\mathbf{0 . 4 3 1} * * * \\
(0.000)\end{array}$ & Constant \\
\hline Prog. Assistance & $\begin{array}{l}0.001 \\
(0.251)\end{array}$ & $\begin{array}{l}0.002 \\
(0.142)\end{array}$ & $\begin{array}{l}0.002 \\
(0.103)\end{array}$ & $\begin{array}{l}0.002 * \\
(0.090)\end{array}$ & Prog. Assistance (-1) \\
\hline Action on Debt & $\begin{array}{l}-0.007 * * * \\
(0.000)\end{array}$ & $\begin{array}{l}-0.008 * * * \\
(0.000)\end{array}$ & $\begin{array}{l}-0.007 * * * \\
(0.000)\end{array}$ & $\begin{array}{l}-0.008 * * * \\
(0.000)\end{array}$ & Action on Debt $(-1)$ \\
\hline Hum. Assistance & $\begin{array}{l}0.001 \\
(0.551)\end{array}$ & $\begin{array}{l}0.002 \\
(0.421)\end{array}$ & $\begin{array}{l}0.002 \\
(0.354)\end{array}$ & $\begin{array}{l}0.001 \\
(0.558)\end{array}$ & Hum. Assistance (-1) \\
\hline Social Infrastructure & $\begin{array}{l}\mathbf{0 . 0 2 0} * * * \\
(\mathbf{0 . 0 0 0 )}\end{array}$ & --- & --- & --- & Social Infrastructure(-1) \\
\hline Econ. Infrastructure & --- & $\begin{array}{l}\mathbf{0 . 0 0 3} * * * * \\
(\mathbf{0 . 0 0 2})\end{array}$ & --- & --- & Econ. Infrastructure $(-1)$ \\
\hline Productive Sector & --- & --- & $\begin{array}{l}0.007 * \\
(0.068)\end{array}$ & --- & Productive Sector(-1) \\
\hline Multi Sector & --- & --- & --- & $\begin{array}{l}0.004 \\
(0.148)\end{array}$ & Multi Sector(-1) \\
\hline Hausman & $39.984 * * *$ & $66.307 * * *$ & $37.034 * * *$ & $44.23 * * *$ & Hausman \\
\hline Within $\mathrm{R}^{2}$ & 0.341 & 0.326 & 0.331 & 0.312 & Within $\mathrm{R}^{2}$ \\
\hline $\mathrm{LSDV} \mathrm{R}^{2}$ & 0.983 & 0.983 & 0.983 & 0.983 & $\mathrm{LSDV} \mathrm{R}^{2}$ \\
\hline Fisher (LSDV) & $257.11 * * *$ & $251.38 * * *$ & $253.45 * * *$ & $246.14 * * *$ & Fisher \\
\hline Countries & 42 & 42 & 42 & 42 & Countries \\
\hline Observations & 236 & 236 & 236 & 236 & Observations \\
\hline
\end{tabular}

Non-Contemporary effects

$\begin{array}{llll}\mathbf{0 . 4 0 8} * * * & \mathbf{0 . 4 4 3} * * * & \mathbf{0 . 4 3 6} * * * & \mathbf{0 . 4 4 1} * * * \\ \mathbf{( 0 . 0 0 0 )} & (\mathbf{0 . 0 0 0 )} & \mathbf{( 0 . 0 0 0 )} & \mathbf{( 0 . 0 0 0 )} \\ -0.0005 & -0.0005 & -0.00002 & 0.0001 \\ (0.733) & (0.721) & (0.988) & (0.932) \\ \mathbf{- 0 . 0 0 6} * * * & \mathbf{- 0 . 0 0 6 * * *} & \mathbf{- 0 . 0 0 6} * * * & \mathbf{- 0 . 0 0 6 * * *} \\ \mathbf{( 0 . 0 0 0 )} & (\mathbf{0 . 0 0 0 )} & \mathbf{( 0 . 0 0 0 )} & \mathbf{( 0 . 0 0 0 )} \\ -0.0009 & 0.0001 & 0.0009 & -0.0004 \\ (0.704) & (0.957) & (0.735) & (0.879) \\ \mathbf{0 . 0 1 9} * * * & --- & -- & -- \\ (\mathbf{0 . 0 0 0 )} & & & \\ --- & \mathbf{0 . 0 0 5} * * * & --- & -- \\ & (\mathbf{0 . 0 0 0 )} & & \\ --- & -- & \mathbf{0 . 0 0 9} * * & -- \\ & & (\mathbf{0 . 0 2 1}) & \\ --- & -- & --- & 0.006 \\ & & & (0.104) \\ \mathbf{2 9 . 6 9 2} * * * & \mathbf{6 0 . 0 4} * * * & \mathbf{2 6 . 3 1} * * * & \mathbf{3 3 . 3 3} * * * \\ 0.264 & 0.288 & 0.281 & 0.246 \\ 0.986 & 0.987 & 0.986 & 0.986 \\ \mathbf{2 7 8 . 6 8} * * * & \mathbf{2 8 8 . 0 2} * * * & \mathbf{2 8 5 . 2 3} * * * & \mathbf{2 7 1 . 8 6} * * * \\ 41 & 41 & 41 & 41 \\ 211 & 211 & 211 & 211\end{array}$

***,***: significance levels at 1\%,5\% and 10\% respectively. Econ: Economic. Prog: Programme. Hum: Humanitarian. LSDV: Least Squares Dummy Variable. HAC SE: Heteroscedasticity \& Autocorrelation Consistent Standard Errors. OLS: Ordinary Least Squares.

Table 4 below presents the dynamic system GMM findings and comparative full specifications for further robustness purposes. The latter in Panel B is based on the relaxation of concerns about multicollinearity and overparameterization. Hence, all aid variables enter into the specifications. The findings which are based on contemporary and non-contemporary OLS and FE regressions confirm the results of Table 3.

Table 4: Dynamic GMM and comparative full specifications 


\begin{tabular}{|c|c|c|c|c|c|c|c|c|c|}
\hline \multirow[b]{3}{*}{ IHDI(-1) } & \multirow{2}{*}{\multicolumn{5}{|c|}{$\begin{array}{c}\text { Dynamic System GMM } \\
\text { Contemporary and Non-contemporary }\end{array}$}} & \multicolumn{2}{|c|}{ Baseline HAC SE OLS } & \multicolumn{2}{|c|}{ Fixed-Effects HAC SE } \\
\hline & & & & & & \multicolumn{2}{|c|}{ Cont Non-cont } & \multicolumn{2}{|c|}{ Cont Non-con } \\
\hline & $\begin{array}{l}0.986 * * * \\
(0.000)\end{array}$ & $\begin{array}{l}0.992 * * * \\
(0.000)\end{array}$ & $\begin{array}{l}0.989 * * * \\
(0.000)\end{array}$ & $\begin{array}{l}0.993 * * * \\
(0.000)\end{array}$ & $\begin{array}{l}0.970 * * * \\
(0.000)\end{array}$ & --- & --- & --- & --- \\
\hline Constant & $\begin{array}{l}0.004 \\
(0.400)\end{array}$ & $\begin{array}{l}0.008 \\
(0.283)\end{array}$ & $\begin{array}{l}0.006 \\
(0.360)\end{array}$ & $\begin{array}{l}0.009 \\
(0.180)\end{array}$ & $\begin{array}{l}0.002 \\
(0.605)\end{array}$ & $\begin{array}{l}0.485 * * * \\
(0.000)\end{array}$ & $\begin{array}{l}0.473 * * * \\
(\mathbf{0 . 0 0 0 )}\end{array}$ & $\begin{array}{l}0.391 * * * \\
(0.000)\end{array}$ & $\begin{array}{l}0.408 * * * \\
(0.000)\end{array}$ \\
\hline Prog. Assistance & $\begin{array}{l}\text { 0.0008* } \\
(0.058)\end{array}$ & $\begin{array}{l}0.0005 \\
(0.244)\end{array}$ & $\begin{array}{l}0.0009 \\
(0.100)\end{array}$ & $\begin{array}{l}0.0006 \\
(0.103)\end{array}$ & $\begin{array}{l}\mathbf{0 . 0 0 1} * * * \\
(0.000)\end{array}$ & $\begin{array}{l}-\mathbf{0 . 0 3 6} * * * \\
(\mathbf{0 . 0 0 0 )}\end{array}$ & $\begin{array}{l}-\mathbf{0 . 0 3 5} * * * \\
(\mathbf{0 . 0 0 0 )}\end{array}$ & $\begin{array}{l}0.001 \\
(0.365)\end{array}$ & $\begin{array}{l}-0.001 \\
(0.362)\end{array}$ \\
\hline Action on Debt & $\begin{array}{l}0.0007 * \\
(0.073)\end{array}$ & $\begin{array}{l}0.0004 \\
(0.323)\end{array}$ & $\begin{array}{l}0.0008 * * \\
(0.041)\end{array}$ & $\begin{array}{l}0.0004 \\
(0.343)\end{array}$ & $\begin{array}{l}0.001 * * * \\
(0.004)\end{array}$ & $\begin{array}{l}-0.002 \\
(0.690)\end{array}$ & $\begin{array}{l}-0.003 \\
(0.565)\end{array}$ & $\begin{array}{l}-0.007 * * * \\
(0.000)\end{array}$ & $\begin{array}{l}-0.005 * * * \\
(0.000)\end{array}$ \\
\hline Hum. Assistance & $\begin{array}{l}-0.001 \\
(0.210)\end{array}$ & $\begin{array}{l}-0.001 \\
(0.222)\end{array}$ & $\begin{array}{l}-0.001 \\
(0.306)\end{array}$ & $\begin{array}{l}-0.001 \\
(0.103)\end{array}$ & $\begin{array}{l}-0.002 * * \\
(0.019)\end{array}$ & $\begin{array}{l}-\mathbf{0 . 0 4 3} * * * \\
(\mathbf{0 . 0 0 1})\end{array}$ & $\begin{array}{l}-\mathbf{0 . 0 4 5} * * * \\
(\mathbf{0 . 0 0 0 )}\end{array}$ & $\begin{array}{l}0.003 \\
(0.305)\end{array}$ & $\begin{array}{l}0.0005 \\
(0.836)\end{array}$ \\
\hline Social Infrastructure & $\begin{array}{l}0.002 \\
(0.195)\end{array}$ & --- & --- & --- & $\begin{array}{l}0.006 * * * \\
(0.000)\end{array}$ & $\begin{array}{l}0.004 \\
(0.862)\end{array}$ & $\begin{array}{l}0.015 \\
(0.520)\end{array}$ & $\begin{array}{l}0.391 * * * \\
(0.000)\end{array}$ & $\begin{array}{l}\mathbf{0 . 0 1 2} * * \\
(\mathbf{0 . 0 3 3 )}\end{array}$ \\
\hline Econ. Infrastructure & --- & $\begin{array}{l}0.008 \\
(0.301)\end{array}$ & --- & --- & $\begin{array}{l}-0.0001 \\
(0.805)\end{array}$ & $\begin{array}{l}0.036 * * * \\
(0.001)\end{array}$ & $\begin{array}{l}\mathbf{0 . 0 4 3} * * * \\
(0.000)\end{array}$ & $\begin{array}{l}0.016 * * * \\
(0.000)\end{array}$ & $\begin{array}{l}\mathbf{0 . 0 0 4} * * * \\
(0.002)\end{array}$ \\
\hline Productive Sector & --- & --- & $\begin{array}{l}\mathbf{0 . 0 0 2} * * * \\
(\mathbf{0 . 0 0 8 )}\end{array}$ & --- & $\begin{array}{l}0.0003 \\
(0.686)\end{array}$ & $\begin{array}{l}-0.013 \\
(0.373)\end{array}$ & $\begin{array}{l}-0.022 \\
(0.167)\end{array}$ & $\begin{array}{l}0.002 * * \\
(0.042)\end{array}$ & $\begin{array}{l}\text { 0.006* } \\
(0.098)\end{array}$ \\
\hline Multi Sector & --- & --- & --- & $\begin{array}{l}-0.0003 \\
(0.757)\end{array}$ & $\begin{array}{l}\text { 0.001*** } \\
(0.040)\end{array}$ & $\begin{array}{l}0.018 \\
(0.356)\end{array}$ & $\begin{array}{l}0.016 \\
(0.446)\end{array}$ & $\begin{array}{l}0.005 \\
(0.117)\end{array}$ & $\begin{array}{l}0.001 \\
(0.678)\end{array}$ \\
\hline $\operatorname{AR}(1)$ & $(0.117)$ & $(0.114)$ & $(0.096)$ & (0.119) & $(0.122)$ & --- & --- & --- & --- \\
\hline $\operatorname{AR}(2)$ & $(0.784)$ & $(0.516)$ & $(0.569)$ & $(0.918)$ & $(0.574)$ & --- & --- & --- & --- \\
\hline Sargan OIR & $(0.232)$ & $(0.143)$ & $(0.098)$ & $(0.243)$ & $(0.116)$ & --- & --- & --- & --- \\
\hline Hansen OIR & $(0.441)$ & $(0.497)$ & (0.279) & $(0.364)$ & $(0.639)$ & --- & --- & --- & --- \\
\hline $\begin{array}{l}\text { DHT for instruments } \\
\text { (a)Instruments in levels }\end{array}$ & & & & & & & & & \\
\hline H excluding group & $(0.650)$ & $(0.688)$ & $(0.587)$ & $(0.707)$ & $(0.470)$ & --- & --- & --- & --- \\
\hline $\begin{array}{l}\text { Dif(null, H=exogenous) } \\
\text { (b) IV (years, eq (diff)) }\end{array}$ & $(0.303)$ & $(0.341)$ & (0.180) & $(0.214)$ & (0.641) & --- & --- & --- & --- \\
\hline $\mathrm{H}$ excluding group & $(0.311)$ & $(0.619)$ & $(0.368)$ & $(0.794)$ & $(0.500)$ & --- & --- & --- & --- \\
\hline Dif(null, H=exogenous) & $(0.565)$ & $(0.317)$ & $(0.249)$ & $(0.114)$ & $(0.708)$ & --- & --- & --- & --- \\
\hline Hausman & --- & --- & --- & --- & --- & --- & --- & $78.01 * * *$ & $68.23 * * *$ \\
\hline Adjusted R ${ }^{2}$ & --- & --- & --- & --- & --- & 0.374 & 0.408 & --- & --- \\
\hline Within $\mathrm{R}^{2}$ & --- & --- & --- & --- & --- & --- & --- & 0.370 & 0.337 \\
\hline $\mathrm{LSDV} \mathrm{R}^{2}$ & --- & --- & --- & --- & --- & --- & --- & 0.984 & 0.987 \\
\hline Fisher (LSDV) & --- & --- & --- & --- & --- & --- & --- & 248.42*** & $284.69 * * *$ \\
\hline Fisher & $1835 * * *$ & $1611 * * *$ & $2033 * * *$ & $2312 * * *$ & $11324 * * *$ & $21.083 * * *$ & 21.718*** & --- & --- \\
\hline Instruments & 25 & 25 & 25 & 25 & 37 & --- & --- & --- & --- \\
\hline Countries & 38 & 38 & 38 & 38 & 38 & 42 & 41 & 42 & 41 \\
\hline$\underset{£}{\text { Observations }}$ & 187 & 187 & 187 & 187 & 187 & 236 & 211 & 236 & 211 \\
\hline
\end{tabular}

***,****: significance levels at 1\%,5\% and 10\% respectively. Econ: Economic. Prog: Programme. Hum: Humanitarian. DHT: Difference in Hansen Test for Exogeneity of Instruments' Subsets. Dif: Difference. OIR: Over-identifying Restrictions Test. The significance of bold values is twofold, (1) The significance of estimated coefficients, Hausman test and the Fisher statistics 2) The failure to reject the null hypotheses of: a) no autocorrelation in the $\operatorname{AR}(1) \& \operatorname{AR}(2)$ tests and b) the validity of the instruments in the Sargan OIR test. LSDV: Least Squares Dummy Variable. Cont: Contemporary. Non-cont: Non-contemporary. HAC SE: Heteroscedasticity \& Autocorrelation Consistent Standard Errors. OLS: Ordinary Least Squares.

As for Panel A, while the first-four specifications control for multicollinearity, the fifth specification relaxes the assumption. First, in relation to previous findings/modelling, while the negative sign of the humanitarian assistance variable remains unchanged, the effects of programme assistance and action on debt are now positive. The reason for this difference could be traceable to the drop in cross-sections from 42(41) to 38. This drop is accompanied by a decrease in degrees of freedom. Another possible explanation could be the result of controlling for time-effects. Second, the effects of the aid dynamics with some high degree of substitution are positive, with the exception of the impact of economic infrastructure. 
The post-estimation tests confirm the validity of the instruments and absence of autocorrelation. Accordingly, the null hypotheses of the difference-in-Hansen test for instrument exogeneity and Arellano and Bond (1991) autocorrelation test are not rejected.

After cross-examining the OLS, FE and GMM results, only the effects of program assistance and action on debt are ambiguous. The majority of the aid variables are unambiguous in terms of consistency in signs of estimated coefficients. Hence, in the concluding implications that follow, we urge the reader to consider the expositional/cautious character of the discussions related to the ambiguous-side of results.

\section{Concluding implications}

The use of foreign aid as a policy instrument to promote development in recipient countries has been the object of much debate (Gibson et al., 2014; Arvin \& Barillas, 2002; Arvin et al., 2002; Balde, 2011) $)^{5}$. We resist the need for engaging in the debate over whether foreign aid is generally good or bad. Such engagement would be irrelevant for two main reasons. First, development assistance is like a policy, whose outcome depends on its implementation. Second, while Donors may have some strategic interests, recipients also have their fair share of blame any fault in allocated funds.

The following findings have been established. First, the impact of aid dynamics with high degrees of substitution are positive. These include, aid for: social infrastructure, economic infrastructure, the productive sector and the multi-sector. Second, the effect of humanitarian assistance is consistently negative across specifications and models. Third, the effects of programme assistance and action on debts are ambiguous because they become positive with the GMM technique.

Given the substantial reliance of the African continent on development assistance, the findings have implications for promoting inclusive human development with specific aid programmes. Hence, multilateral development agencies like the African Development Bank (AfDB) with a strategic focus on infrastructural development should be continuously supported by developed countries in their efforts toward infrastructural improvement for inclusive human development. Hence, given the established positive relationship between inclusive human development and foreign aid allocated for infrastructural development, we can only encourage the current strategy of the AfDB.

\footnotetext{
${ }^{5}$ Inter alia: the interested reader can consider: (1) Efobi et al. (2014) versus (vs) Asongu (2012) and Okada and Samreth (2012); (2) Eubank (2012) vs Asongu (2015b) and; (3) Kangoye (2013) vs Asongu (2014b).
} 
The negative effect of humanitarian assistance implies that mechanisms by which such funds are channelled may be reconsidered. This is consistent with a study partially motivating this line of inquiry: "Though the stated intents or purposes of aid are socio-economic, the actual impact from the findings negates this. It is a momentous epoque to solve the second tragedy of foreign aid; it is high time economists and policy makers start rethinking the models and theories on which foreign aid is based. In the meantime, it is up to people who care about the poor to hold aid agencies accountable for piecemeal results" (Asongu, 2014a, p. 455).

In the light of the above, we provide some recommendations for rethinking of theories and models on which development assistance is based. Drawing on Piketty's who has substantially debunked the Kuznets' conjectures to which many foreign aid policies have been aligned, we suggest that developed countries should orient developing nations towards industrialisation by focusing more on inequality and less on economic growth. This is broadly consistent with an evolving narrative on inequality in Africa (Elu, 2013; Mthuli et al., 2014; Brada \& Bah, 2014; Asongu et al., 2015; Anyanwu, 2011, 2014).

By tailoring aid to focus on inequality instead of growth, there is some room for optimism that the transition from MDGs to SDGs would deliver inclusive outcomes from development assistance. This is essentially because the inequality elasticity of poverty is higher than the growth elasticity of poverty because the response of poverty to growth is a decreasing function of inequality. The underlying need to place more emphasis on inequality as opposed to growth has also been documented for the sampled countries by Fosu (2008, 2009, 2010abc, 2011). We lift verbatim a few conclusions to support the policy recommendation: "The study finds that the responsiveness of poverty to income is a decreasing function of inequality" (Fosu, 2010c, p. 818); “The responsiveness of poverty to income is a decreasing function of inequality, and the inequality elasticity of poverty is actually larger than the income elasticity of poverty" (Fosu, 2010a, p. 1432); and "In general, high initial levels of inequality limit the effectiveness of growth in reducing poverty while growing inequality increases poverty directly for a given level of growth" (Fosu, 2011, p. 11).

We do not resist the need to provide some discussion on the ambiguous results from action on debt. According to Boyce and Ndikumana (2011), such action is motivated by at least three reasons: (i) past debts have not benefitted the poor; (ii) borrowing arrangements were without popular consent and (iii) historical evidence shows 'creditor awareness' of recipients' insolvency. Hence, a priori, the results are expected to positively impact human 
development because debt cancellation/reduction reflects positive macroeconomic income/fiscal externalities that should be reinvested domestic economies to enhance human development. The ambiguity in results is broadly consistent with Asongu et al. (2015) who have confirmed the Azzimonti et al. (2014) conclusions that globalisation-driven debts increase income-inequality. Their findings, which are based on the same periodicity and sample (as in this study), show that the effect on inclusive human development depends on whether the debts are interactive with or endogenous to globalisation.

Overall, while the findings are broadly consistent with Asiedu (2014), GyimahBrempong and Racine (2014) and Kargbo \& Sen (2014), they also raise some questions on previous foreign aid literature. For instance, humanitarian assistance which survives salient criticisms from Moyo's Dead Aid has been established to have a negative effect on inclusive human development. Moreover the Fofack (2014) conjecture on self-reliance as means to African development is not consistent with the findings.

As a technical policy implication, like in Efobi et al. (2014), distinguishing types of foreign aid is critical to advancing empirical conclusions on the aid-development nexus. This is essentially because previous findings using the same dependent variable that have grouped aid as a single indicator have shown a negative effect (Asongu, 2014a), a tendency that is consistent across conditional distributions of the dependent variable (Asongu, 2014c).

When the findings are considered in the light of the deep policy challenges of our time, the principal social implication is that foreign aid can be instrumental in inclusive capitalism. It could be used to avoid/mitigate the setbacks of the Kuznets theory and help developing countries embrace globalisation/industrialisation in the light of Piketty. Foreign aid can be instrumental in inclusive human development if the above measures are considered, inter alia: in (i) stimulating the knowledge economy which has been established to reduce inequality (Lustig, 2011) and (ii) emphasising gender equality. These are clearly avenues of future research that should go a long way to clarifying provocative titles like 'foreign aid follies' (Rogoff, 2014) or sceptical conclusions from more substantive surveys from 40 years of foreign aid (Doucouliagos \& Paldam, 2008, 2009).

\section{References}


Alan, K., \& Carlyn, R-D., (2015). “Is Africa Actually Developing?”, World Development, 66(C), pp. 598-613.

Amavilah, V. H. S., (2014). "Sir W. Arthur Lewis and the Africans: Overlooked Economic Growth Lessons”, MPRA Working Paper No. 57126.

Amin, S., (2014). “Aid for Development”, Springer Briefs on Pioneers in Science and Practice, 16, pp. 125-137.

Anyanwu, J. C., (2014). "Determining the correlates of poverty for inclusive growth in Africa," European Economic Letters, 3(1), pp. 12-17.

Anyanwu, J. C., (2011). "International Remittances and Income Inequality in Africa," Review of Economic and Business Studies, Issue 7, pp.117-148.

Arellano, M., \& Bond, S., (1991). "Some Tests of Specification for Panel Data: Monte Carlo Evidence and an Application of Employment Equations" .Review of Economic Studies, 58, pp. 277-297.

Arellano, M., \& Bover, O., (1995). "Another Look at the Instrumental Variable Estimation of Error Component Model”. .Journal of Econometrics, 68, pp. 29-52.

Arvin, B. M., Barillas, F., \& Lew, B., (2002). "Is Democracy a Component of Donors' Foreign Aid Policies?", In: in B. Mak Arvin (ed.) New Perspectives on Foreign Aid and Economic Development. Westport, Connecticut: Praeger, 2002, pp. 171-198.

Arvin, B. M., \& Barillas (2002) "Foreign Aid, Poverty Reduction, and Democracy", Applied Economics, 34(17), pp. 2151-2156.

Asiedu, E. (2014). "Does Foreign Aid in Education Promote Economic Growth? Evidence From Sub-Saharan Africa”, Journal of African Development, 16(1), pp. 37-59.

Asongu, S. A., (2015a). "Reinventing Foreign Aid for Inclusive and Sustainable Development: Kuznets, Piketty and the Great Policy Reversal”, Journal of Economic Surveys: http://onlinelibrary.wiley.com/doi/10.1111/joes.12109/full

Asongu, S. A., (2015b). "On taxation, political accountability and foreign aid: empirics to a celebrated literature", South African Journal of Economics, 83(2), pp. 180-198.

Asongu, S. A. (2012). "On the effect of foreign aid on corruption", Economics Bulletin, 32(3), pp. 2174-2180.

Asongu, S. A. (2013). "On the effectiveness of foreign aid in institutional quality", European Economic Letters, 2(1), pp. 12-19.

Asongu, S. A., (2014a). "The Questionable Economics of Development Assistance in Africa: Hot-Fresh Evidence, 1996-2010", The Review of Black Political Economy, 41(4), pp. 455480. 
Asongu, S. A., (2014b). "On foreign aid distortions to governance", African Governance and Development Institute Working Paper No. 14/003, Yaoundé.

Asongu, S. A., ( 2014c). "Development thresholds of foreign aid effectiveness in Africa", International Journal of Social Economics, 41(11), pp. 1131-1155.

Asongu, S. A., Efobi, U., \& Beecroft, I., (2015). "Inclusive Human Development in Pre-crisis Times of Globalization-driven Debts", African Development Review, 27(4), pp. 428-442.

Asongu, S. A., \& De Moor, L., (2015). "Financial globalisation dynamic thresholds for financial development: evidence from Africa", The European Journal of Development Research: Revised and Resubmitted.

Asongu, S. A., \& Jellal, M. (2013). "On the channels of foreign aid to corruption", Economics Bulletin, 33(3), pp. 2191-2201.

Asongu, S. A. \& Jellal, M. (2016). "Foreign aid fiscal policy: theory and evidence", Comparative Economic Studies: Forthcoming.

Asongu, S. A., \& Kodila-Tedika, O., (2015). "Is Poverty in the African DNA (Gene)?", African Governance and Development Institute Working Paper No. 15/011, Yaoundé.

Asongu, S. A., \& Tchamyou, V. S., (2015). "Foreign Aid, Education and Lifelong Learning in Africa", African Governance and Development Institute Working Paper No. 15/047, Yaoundé.

Azzimonti, M., De Francisco, E., \& Quadrini, V., (2014). "Financial Globalisation, Inequality and the Rising Public Debt”, American Economic Review, 104(8), pp. 2267-2302.

Balde, Y., (2011). "The Impact of Remittances and Foreign Aid on Savings/Investment in Sub-Saharan Africa”, African Development Review, 23(2), pp. 247-262.

Baltagi, B. H., (2008). "Forecasting with panel data", Journal of Forecasting, 27(2), pp. 153173.

Banuri, T., (2013). "Sustainable Development is the New Economic Paradigm", Development, 56(2), pp. 208-217.

Banerjee, A., \& He, R., (2008). "Making Aid Work", In Reinventing Foreign Aid, ed. Easterly, W., The MIT Press: Massachusetts, pp. 47-92.

Bhagwati, J., (1958). "Immiserizing growth: A geometrical note", Review of Economic Studies, 25, pp. 201-205.

Blas, J., (2014). “Inequality mar Africa's rise”, Financial Times (October 5th). http://www.ft.com/intl/cms/s/0/9e74aa50-1e4d-11e4-ab5200144feabdc0.html\#axzz3GWsY4I91 (Accessed: 18/10/2014). 
Boyce J. K., Ndikumana L. (2011), "Capital flight from sub-Saharan Africa: linkages with external borrowing and policy options", International Review of Applied Economics, 25(2), 149-170.

Brada, J. C., \& Bah, E. M. (2014). "Growing Income Inequality as a Challenge to $21^{\text {st }}$ Century Capitalism", Italian Association for the Study of Economic Asymmetries, Working Paper No. 1402.

Caulderwood, K., (2015) "Sub-Saharan Africa Falls Behind In Fight Against Extreme Poverty: World Bank Report", International Business Times (April 14th 2015). http://www.ibtimes.com/sub-saharan-africa-falls-behind-fight-against-extreme-povertyworld-bank-report-1881460 (Accessed: 19/04/2015).

Collier, P. (2007). The Bottom Billion: Why the Poorest Countries Are Failing and What Can Be Done About It ?, Oxford University Press.

Doucougliagos, H., \& Paldam ,M., (2008). “Aid effectiveness on growth: a meta study". European Journal of Political Economy, 24(1), pp. 1-24.

Doucouliagos, H., \& Paldam, M., (2009). "The aid effectiveness literature: the sad results of 40 years of research", Journal of Economic Surveys, 23(3), pp. 433-461.

Duflo, E., \& Kremer, M., (2008). "Use of Randomization in the Evaluation of Development Effectiveness", In Reinventing Foreign Aid, ed. Easterly, W., The MIT Press: Massachusetts, pp. 93-120.

Easterly, W., (2002). "The cartel of good intensions: the problem of bureaucracy in foreign aid", The Journal of Policy Reform, 5(4), pp. 223-250.

Easterly, W., (2006). "Planner versus searchers in foreign aid", Asian Development Review, 23(1), pp. 1-35.

Easterly, W., (2008). Reinventing Foreign Aid, The MIT Press: Massachusetts.

Efobi, U., Beecroft, I., Asongu, S. A., (2014). "Foreign aid and corruption: clarifying murky empirical conclusions", African Governance and Development Institute Working Paper No. $14 / 025$.

Elu J., (2013). "Earnings Inequality and the Intersectionality of Gender and Ethnicity In SubSaharan Africa: The Case of Tanzanian Manufacturing”, American Economic Review, Papers and Proceedings 04/2013, 103(103), pp. 289-292.

Eubank, N. (2012). "Taxation, Political Accountability and Foreign Aid: Lessons from Somaliland", Journal of Development Studies, 48(4), pp. 465-480.

Fofack, H., (2014). “The Idea of Economic Development: Views from Africa”, WIDER Working Paper 2014/093, Helsinki. 
Fosu, A. K., (2015a). "Growth, Inequality and Poverty in Sub-Saharan Africa: Recent Progress in a Global Context", Oxford Development Studies, 43(1), pp. 44-59.

Fosu, A. K. (2015b). Growth and Institutions in African Development, First edited by Augustin K. Fosu, , Routledge Studies in Development Economics: New York.

Fosu, A. K. (2015c). Growth and institutions in African Development, in Growth and Institutions in African Development, First edited by Augustin K. Fosu, 2015, Chapter 1, pp. 1-17, Routledge Studies in Development Economics: New York.

Fosu, A. K., (2008). "Inequality and the Growth-Poverty Nexus: Specification Empirics Using African Data”, Applied Economics Letters, 15(7), pp. 563-566.

Fosu, A. K., (2009). "Inequality and the Impact of Growth on Poverty: Comparative Evidence for Sub-Saharan Africa”, Journal of Development Studies, 45(5), pp. 726-745.

Fosu, A. K., (2010a). "Inequality, Income and Poverty: Comparative Global Evidence", Social Sciences Quarterly, 91(5), pp. 1432-1446.

Fosu, A. K., (2010b). "The Effect of Income Distribution on the Ability of Growth to Reduce Poverty: Evidence from Rural and Urban African Economies", American Journal of Economics and Sociology, 69(3), pp. 1034-1053.

Fosu, A. K., (2010c). "Does Inequality Constrain Poverty Reduction Programs? Evidence from Africa", Journal of Policy Modeling, 32(6), pp. 818-827.

Fosu, A. K., (2011). "Growth, Inequality and Poverty Reduction in Developing Countries: Recent Global Evidence”, UNU WIDER Working Paper 2011/01.

Ghosh, J., (2013). “Towards a Policy Framework for Reducing Inequalities”, Development, 56(2), pp. 218-222.

Gibson, C., Hoffman, B., \& Jablonski, R., (2014). "Did Aid Promote Democracy in Africa? The Role of Technical Assistance in Africa's Transitions", University of California, San Diego.

http://ryanjablonski.files.wordpress.com/2014/05/did-aid-promote-democracy-in-africa.pdf (Accessed: 05/06/2014).

Gyimah-Brempong, K., \& Racine, J. S. (2014). "Aid and Economic Growth: A Robust Approach”, Journal of African Development, 16(1), pp. 1-35.

Jones, S., Page, J., Shimeles, A., \& Tarp, F., (2015). "Aid, Growth and Employment in Africa", African Development Review, Supplement: Special Issue on "Aid and Employment", 27, ( S1), pp. 1-4. 
Jones, S., \& Tarp, F., (2015). "Priorities for Boosting Employment in Sub-Saharan Africa: Evidence for Mozambique", African Development Review, Supplement: Special Issue on "Aid and Employment", 27,( S1), pp. 56-70.

Kangoye, T., (2013). "Does Aid Unpredictability Weaken Governance? Evidence From Developing Countries", The Developing Economies, 51(2), pp. 121-144.

Kargbo, P. M., \& Sen, K., (2014). "Aid Categories that Foster Pro-Poor Growth: The Case of Sierra Leone”, African Development Review, 26(2), pp. 416-429.

Kindiki, M. M., (2011). "International Regime Governance and Apparel Labour Upgrading in Export Processing Zones in Urban Kenya", African Review of Economics and Finance, 3(1), pp. 26-40.

Klugman, J., (2002). "A Sourcebook for Poverty Reduction Strategies", The World Bank, Washington DC.

Krause, U., (2013). "Innovation: The new Big Push or the Post-Development alternative?", Development, 56(2), pp. 223-226.

Kremer, M., (2008). "Making Vaccines Pay", In Reinventing Foreign Aid, ed. Easterly, W., The MIT Press: Massachusetts, pp. 417-430.

Kuada, J., (2015). Private Enterprise-Led Economic Development in Sub-Saharan Africa The Human Side of Growth First edition by Kuada, J, Palgrave Macmillan: New York.

Kuznets, S. (1955). "Economic Growth and Income Inequality". American Economic Review, 45, pp. $1-28$.

Kuznets, S., (1971). Economic Growth of Nations: Total Output and Production Structure. Belknap Press/Harvard University Press: Cambridge (Mass).

Leautier, F. A., (2012). "What Role for Africa After 50 Years of Independence: Provider of Natural Resources or a New Global Leader?", Journal of African Development, 14(1), pp. 127-151.

Lewis, A., (1955). Theory of Economic Growth. Milton Park: Routledge.

Love, I., \& Zicchino, L., (2006). "Financial Development and Dynamic Investment Behaviour: Evidence from Panel VAR". The Quarterly Review of Economics and Finance, 46, pp. 190-210.

Lustig, N., (2011). “The Knowledge Bank and Poverty Reduction”, Working Papers 209, ECINEQ, Society for the Study of Economic Inequality. Marglin, S. A. (2013). "Premises for a New Economy", Development, 56(2), pp. 149-154.

Marglin, S. A. (2013). "Premises for a New Economy", Development, 56(2), pp. 149-154. Milburn, R., (2013). "Idealism in Reality Check", PENTA DAILY, http://blogs.barrons.com/penta/2013/09/12/idealisms-reality-check/ (Accessed: 29/08/2014). 
Monni, S., \& Spaventa, A., (2013). "Beyond GDP and HDI: Shifting the focus from paradigms to politics", Development, 56(2), pp. 227-231.

Moyo, D., (2009). Dead Aid: Why Aid Is Not Working and How There is Another Way for Africa. New York: Farrar, Straus and Giroux.

Mthuli, N., Anyanwu, J. C., \& Hausken, K., (2014). "Inequality, Economic Growth and Poverty in the Middle East and North Africa (MENA)", African Development Review, 26(3), pp. 435-453.

Ndlovu-Gatsheni, S. J. (2013). "The Entrapment of African within the Global Colonial Matrices of Power: Eurocentrism, Coloniality and Deimperialieation in the Twenty-first century", Journal of Developing Societies, 29(4), pp. 331-353.

Obeng-Odoom, F. (2013). "Africa's Failed Economic Development Trajectory: A Critique”, African Review of Economics and Finance, 4(2), pp. 151-175.

Obeng-Odoom, F. (2014). “Africa: On the Rise, but to Where?”, Forum for Social Economics, DOI: 10.1080/07360932.2014.955040.

Okada, K., \& Samreth, S. (2012). "The effect of foreign aid on corruption: A quantile regression approach", Economic Letters, 11, pp. 240-243.

Osabuohien, E. S., \& Efobi, E. R., (2013). “Africa's Money in Africa”, South African Journal of Economics, 81(2), pp. 292-306.

Osabuohien, E. (Ed.) (2015).Handbook of Research on In-country Determinants and Implications with Foreign Land Acquisitions. New York: IGI Global.

Page, J., \& Shimeles, A., (2015). "Aid, Employment and Poverty Reduction in Africa", African Development Review, Supplement: Special Issue on "Aid and Employment", 27,(S1), pp. 17-30.

Page, J., \& Söderbom, M., (2015). "Is Small Beautiful? Small Enterprise, Aid and Employment in Africa", African Development Review, Supplement: Special Issue on "Aid and Employment", 27,(S1), pp. 44-55.

Piketty, T., (2014). “Capital in the Twenty First Century”, Harvard University Press.

Pinkivskiy, M., \& Sala-i-Martin, X., (2014). "Africa is on time", Journal of Economic Growth, 19(3), pp. 311-333.

Pritchett, L., (2008). "It Pays to Be Ignorant: A Simple Political Economy of Rigorous Program Evaluation", In Reinventing Foreign Aid, ed. Easterly, W., The MIT Press: Massachusetts, pp. 121-144. 
Pritchett, L., \& Woolcook, M., (2008). "Solutions When the Solution Is the Problem: Arraying the Disarray in Development", In Reinventing Foreign Aid, ed. Easterly, W., The MIT Press: Massachusetts, pp. 147-178.

Radelet, S., \& Levine, R., (2008). "Can We Build a Better Mousetrap? Three New Institutions Designed to Improve Aid Effectiveness", In Reinventing Foreign Aid, ed. Easterly, W., The MIT Press: Massachusetts, pp. 431-460.

Reynolds, A., (2014). "Why Piketty's Wealth Data Are Worthless", CATO INSTITUTE, http://www.cato.org/publications/commentary/why-pikettys-wealth-data-areworthless?utm_source $=$ dlvr.it\&utm_medium $=$ twitter\&utm_campaign=Feed\%3A+CatoRecent Opeds+(Cato+Recent+Op-eds) (Accessed: 02/09/2014).

Rogoff, K., (2014). "Foreign-Aid Follies", Project Syndicate, https://www.projectsyndicate.org/commentary/kenneth-rogoff-urges-caution-in-helping-poor-countries-todevelop (Accessed: 30/08/2014).

Roodman, D., (2009a). "A Note on the Theme of Too Many Instruments", Oxford Bulletin of Economics and Statistics, 71(1), pp. 135-158.

Roodman, D., (2009b). "How to do xtabond2: An introduction to difference and system GMM in Stata", Stata Journal, 9(1), pp. 86-136.

Simpasa, A, Shimeles, A., \& Salami, A. O., "Employment Effects of Multilateral Development Bank Support: The Case of the African Development Bank", African Development Review, Supplement: Special Issue on "Aid and Employment", 27,( S1), pp. 3143.

Titumir, R. A. M., \& Kamal, M. (2013). “Growing Together Sustainably: A zero-poverty post 2015 development framework”, Development, 56(2), pp. 172-184.

United Nations (2013). "A New Global Partnership: Eradicate Poverty and Transform Economies Through Sustainable Development", The Report of the High-Level Panel of Eminent Persons on the Post-2015 Development Agenda.

http://www.un.org/sg/management/pdf/HLP_P2015_Report.pdf (Accessed: 31/08/2014).

Wamboye, E., Adekola, A., \& Sergi, B. S. (2013). "Economic Growth and the Role of Foreign Aid in Selected African Countries", Development, 56(2), pp. 155-171.

Young, A., (2012). "The African growth miracle”, Journal of Political Economy, 120 (4), pp. 696-739. 